\title{
Prognostic relevance of topoisomerase II a and minichromosome maintenance protein 6 expression in colorectal cancer
}

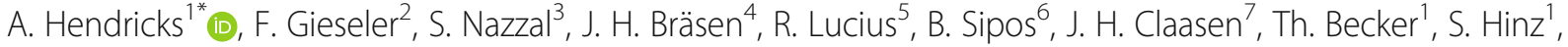 \\ G. Burmeister ${ }^{1}$, C. Schafmayer ${ }^{1}$ and C. Schrader ${ }^{8}$
}

\begin{abstract}
Background: Despite rising incidence rates of colorectal malignancies, only a few prognostic tools have been implemented in proven clinical routine. Cell division and proliferation play a significant role in malignancies. In terms of colorectal cancer, the impact of proliferation associated proteins is controversially debated. The aim of our study was to examine the expression of topoisomerase II a and minichromosome maintenance protein 6 and to correlate these findings with the clinical data.

Methods: Tissue samples of 619 patients in total were stained using the antibodies Ki-S4 and Ki-MCM6 targeting topoisomerase II a as well as minichromosome maintenance protein 6 . The median rate of proliferation was correlated with clinical and follow up data.

Results: The expression rate of minichromosome maintenance protein 6 is significantly higher than the proportion of topoisomerase II a in tumour cells $(p<0.001)$. A high expression of both proteins coincides with a beneficial outcome for the patient, indicating a favourable prognostic marker $(p<0.001$ and $p=0.008)$.

Conclusions: We have demonstrated that high expression rates of proliferative markers is linked to a beneficial patient outcome. According to the general opinion, a high expression rate correlates with a poor patient outcome. In this study, we were able to refute this assertion.
\end{abstract}

Keywords: Colorectal cancer, Proliferative proteins, Minichromosome maintenance protein 6, Topoisomerase II a, Prognostic marker

\section{Background}

Colorectal malignancies are a major cause of death in industrialised countries. Most colorectal neoplasms are histologically adenocarcinomas and develop through an adenoma-carcinoma sequence which was first described by Vogelstein and Fearon [1]. The development of a colorectal carcinoma depends on various factors and may often span over years before a manifest malignancy occurs. The macroscopic shape, histological type and grading seem to play key roles in the transformation process as defined by the adenoma-carcinoma sequence.

\footnotetext{
* Correspondence: alexander.hendricks@uksh.de

'Department of General and Thoracic Surgery, University Hospital Schleswig-Holstein, Campus Kiel, Arnold-Heller Str. 3, Hs. 18, 24105 Kiel, Germany

Full list of author information is available at the end of the article
}

Also, genetic mutations significantly affect the likelihood of colorectal cancer formation [2].

Mitosis within the neoplasia plays a key role in the histopathological analysis of the tumour. Assessment of the proliferation rate by means of proliferation markers is routinely implemented in histological diagnostics. Monoclonal antibodies against antigens associated with cell proliferation, such as Ki-67 [3, 4] and proliferating cell nuclear antigen (PCNA) are part of routine diagnosis in malignancies. Besides these mentioned proteins there are additional proliferation associated proteins, such as topoisomerase II $\alpha$ (Topo II $\alpha$ ) and the minichromosome maintenance protein 6 (MCM6), that can be detected by immunohistochemistry (IHC) $[5,6]$. The group of topoisomerases comprises up to four enzymes that are essential in the DNA topology and crucial for

C The Author(s). 2019 Open Access This article is distributed under the terms of the Creative Commons Attribution 4.0 International License (http://creativecommons.org/licenses/by/4.0/), which permits unrestricted use, distribution, and reproduction in any medium, provided you give appropriate credit to the original author(s) and the source, provide a link to the Creative Commons license, and indicate if changes were made. The Creative Commons Public Domain Dedication waiver (http://creativecommons.org/publicdomain/zero/1.0/) applies to the data made available in this article, unless otherwise stated. 
DNA replication [7]. By applying the monoclonal antibody Ki-S4, Topo II $\alpha$ can be detected by IHC $[5,8]$. The prognostic significance of expressed Topo II $\alpha$ by Ki-S4 was shown in different studies [9-11]. High rates of expressed Topo II $\alpha$ correspond to an unfavourable clinical outcome. However, only a few studies comprising CRC patients have been published so far. Within these studies, fluorescent in situ hybridization (FISH) was applied to detect the expression rate of Topo II $\alpha$. IHC has not been exerted to evaluate the clinical outcome of patients suffering from colorectal neoplasm yet.

Minichromosome maintenance proteins also play a key role in DNA replication of eukaryotic cells. These proteins are a part of the pre-replication complex, which binds to chromatin and therefore represent an essential role in cell division [12]. Ki-MCM6 is a specific antibody targeting MCM6 that can be used in formalin fixed tissue $[6,13,14]$. Multiple studies have verified the clinical relevance of MCM proteins as proliferation markers in malignant tumours so far [15-17]. Though, to the best of our knowledge, no investigation of the clinical relevance in terms of clinical outcome of MCM6 in colorectal carcinoma patients in a representative cohort has been published.

This publication aims to investigate the clinical relevance of topoisomerase II $\alpha$ and minichromosome maintenance protein 6 as proliferation markers in a representative large cohort of human colorectal carcinoma tissue. Results in terms of immunohistochemical expression are correlated to clinical follow-up data. Furthermore, it has to be investigated, whether the degree of expressed proliferation markers varies between clinical-pathological profiles.

\section{Methods}

\section{Patients}

A total of 619 patients was included in this study. All patients underwent a complete oncological resection of a histologically verified colorectal carcinoma at the Department of General and Thoracic Surgery, University Hospital Schleswig Holstein, Campus Kiel, during the period of 1994 and 2007. The resected tumour tissue was preserved at the Institute of Pathology, University Hospital Schleswig Holstein, Campus Kiel. Clinical and follow up data were gathered retrospectively. All data are shown in Table 1 . The study was approved by the local ethics committee of the Medical Faculty, Christian-Albrechts University Kiel (reference no. A110/99).

\section{Immunohistochemistry}

Formalin fixed tissue embedded in paraffin was cut into 3-5 $\mu \mathrm{m}$ thin slices using a microtome (Jung, Heidelberg, Germany). The sections were transferred to covered microscope slides (Histobond, Marienfeld, Germany) at a temperature of $45-55^{\circ} \mathrm{C}$. Before staining, all slides were applied to $100 \%$ xylol for $10 \mathrm{~min}$ to deparaffinise the tissue.
For rehydration, all slides were transferred into a descending sequence of ethanol $(100,96,70 \%)$ for 3 minutes each.

All sections were stained using haematoxylin-eosin stain. After rehydration, the sections were incubated with $200 \mu \mathrm{l}$ haematoxylin for $10 \mathrm{~min}$ and rinsed with distilled water for $10 \mathrm{~min}$. The sections were then incubated in $400 \mu \mathrm{l}$ eosin for $3 \mathrm{~min}$ and rinsed with distilled water. Finally, all sections were applied to an ascending sequence of ethanol $(70,96,100 \%)$ and subsequently incubated in xylol for $5 \mathrm{~min}$.

\section{Analysis of immunohistochemical staining}

All tissue sections were treated with highly specific monoclonal antibodies against the respective antigen and an indirect detection using a secondary antibody. Endogenous peroxidase was blocked by incubation of the specimens in $4 \mathrm{ml} \mathrm{30 \%} \mathrm{hydrogen} \mathrm{peroxide} \mathrm{and} 200 \mathrm{ml}$ methanol. Antigen retrieval was performed by incubation in $0.01 \mathrm{M}$ citrate buffer solution ( $\mathrm{pH} 6.0$ ) for $3 \mathrm{~min}$ at $100^{\circ} \mathrm{C}$ [18]. In the next step, all sections were rinsed with water and transferred into washing buffer. All tissue samples were incubated with $100 \mu \mathrm{l}$ of the primary antibody (detection of topoisomerase II $\alpha$ : Ki-S4; detection of minichromosome maintenance protein 6: Ki-MCM6; Institute for Haematopathology Kiel, University Hospital Schleswig Holstein, Campus Kiel) at room temperature for $60 \mathrm{~min}$ and afterwards incubated in tris-buffered saline (TBS), washed with water and then moved to TBS. The secondary antibody (Rabbit anti-mouse IgG; E354 DAKO, Hamburg, Germany) was applied at room temperature for $30 \mathrm{~min}$. In the next step, slides were rinsed with water and transferred into washing buffer. The sections were stained with $100 \mu \mathrm{l}$ DAB (Diaminobenzidin, DAKO, Hamburg, Germany) and rinsed twice with distilled water. Nucleus counter staining was achieved by hemalum (Merck, Darmstadt, Germany) incubation for 5 minutes. For dehydration purpose, all specimens were moved along an ascending incubational sequence of ethanol (70, 96 and $100 \%$ ) and incubated twice in xylol.

The tissue specimens on microscopic slides were covered with Pertex (Medite, Burgdorf, Germany) and light microscopy was performed using the Axioskop 40 (Zeiss, Germany). Within each specimen 500 tumour cells in five randomly selected visual fields were examined using a cell counter (Counter AC8, Hecht AG, Sondheim, Germany) at a magnification of 400 times. Areas with exceptional high number of tumour cells were accounted separately as hot spots.

The primary antibodies Ki-S4 and Ki-MCM6 were established beforehand and the specificity was consolidated by Western blot experiments previously $[8,13]$.

\section{Statistical analysis}

Comparative statistical analysis of expressed proliferation markers was performed using Fisher's tests of 
Table 1 Patient demographics, clinical characteristics and univariate analysis (log rank test) influencing the overall survival (OS) disease free survival (DFS)

\begin{tabular}{|c|c|c|c|c|c|}
\hline & N (\%) & OS [months] & $P$ & DFS [months] & $P$ \\
\hline all & $619(100)$ & & & & \\
\hline \multicolumn{6}{|l|}{ age (years) } \\
\hline$<65$ & $303(48.9)$ & n.a. & $<0.001$ & 59.5 & 0.005 \\
\hline$\geq 65$ & $315(50.9)$ & 65.6 & & n.a. & \\
\hline unknown & $1(0.2)$ & & & & \\
\hline \multicolumn{6}{|l|}{ sex } \\
\hline male & $312(50.4)$ & 119.1 & 0.961 & n.a. & 0.218 \\
\hline female & $307(49.5)$ & 104.3 & & n.a. & \\
\hline \multicolumn{6}{|l|}{ tumor site } \\
\hline right colon & $172(27.8)$ & 130.5 & 0.010 & n.a. & 0.299 \\
\hline left colon + rectum & $439(70.1)$ & 69.5 & & n.a. & \\
\hline unknown & $8(1.3)$ & & & & \\
\hline \multicolumn{6}{|l|}{ UICC } \\
\hline $1+\|$ & $297(48.0)$ & 154.6 & $<0.001$ & n.a. & $<0.001$ \\
\hline III & $199(32.1)$ & 87.0 & & 49.8 & \\
\hline IV & $117(18.9)$ & 22.1 & & 13.7 & \\
\hline unknown & $6(1.0)$ & & & & \\
\hline \multicolumn{6}{|l|}{ histological grading } \\
\hline I & $10(1.6)$ & n.a. & $<0.001$ & n.a. & 0.007 \\
\hline$\|$ & 505 (81.6) & 122.4 & & n.a. & \\
\hline III & $102(16.5)$ & 41.8 & & 33.6 & \\
\hline unknown & $2(0.3)$ & & & & \\
\hline \multicolumn{6}{|l|}{ histology } \\
\hline adeno carcinoma & $525(84.9)$ & 122.6 & $<0.001$ & n.a. & 0.010 \\
\hline mucinous carcinoma & $74(12.0)$ & 68.3 & & 40.7 & \\
\hline signet-ring cell carcinoma & $7(1.1)$ & 12.3 & & 9.4 & \\
\hline unknown & $13(2.1)$ & & & & \\
\hline \multicolumn{6}{|l|}{ resection margin } \\
\hline RO & $573(92.6)$ & 15.3 & $<0.001$ & n.a. & $<0.001$ \\
\hline$R 1+R 2$ & $32(5.2)$ & 122.6 & & 10.7 & \\
\hline unknown & $14(2.3)$ & & & & \\
\hline \multicolumn{6}{|l|}{ therapy } \\
\hline sole surgical resection & $229(37.0)$ & & & & \\
\hline + chemotherapy & $136(22.0)$ & & & & \\
\hline + radiation & $10(1.6)$ & & & & \\
\hline + chemoradiation & $111(17.9)$ & & & & \\
\hline + unknown & $133(21.5)$ & & & & \\
\hline
\end{tabular}

All $P$ values in bold, are regarded as statistically significant. Abbreviations: $n$.a. not achieved, UICC Union internationale contre le cancer

significance. The univariate analysis of survival was done using the Log rank test and Kaplan-Meier analysis. The software GraphPad Prism, Version 7.0 (GraphPad Software, La Jolla, CA, USA) was used for statistical analysis. The significance level was set at $5 \%(p<0.05)$.

\section{Results}

Patient cohort and clinical characteristics

The examined cohort consisted of 619 patients (50.4\% male; $49.6 \%$ female). The median age was 65.2 years (mean 66 years; range 29 to 102 years). All considered clinical and histopathological characteristics, had a significant 
impact on the patient outcome in terms of overall survival (OS) and progression-free survival (PFS). However, other parameters like gender and tumour localisation did not have any effect on the outcome (Table 1 ). Patients aged $\geq 65$ years had a significantly worse OS $(p<0.001)$ and PFS $(p=0.005)$. Staging by UICC displayed a significant effect on the OS $(p<$ $0.001)$ and PFS $(p<0.001)$. Patients diagnosed with advanced tumours and local and/or remote metastasis (UICC III + IV) displayed a highly significant poorer outcome. In our view, the cohort represents the general population (Additional file 1: Figure S1 A + B).

\section{Expression of topoisomerase II a correlated to clinic- pathological characteristics}

A quantity of 430 colorectal tissue specimens was procured for evaluation of the Topo II $\alpha$ expression profile. The mean and median expression rate of the entire cohort was 52 and $53.8 \%$. The upper-limit of Topo II $\alpha$ expression was set at $50 \%$. In 267 cases, the degree of expression was $\geq 50 \%$. An example of Topo II $\alpha$ expression is displayed in the Fig. $1 \mathrm{a}+\mathrm{b}$. Patients aged $\geq 65$ years displayed a significantly lower expression of Topo II $\alpha(p=0.005)$. In the assessment of UICC stages, patients with locally advanced disease (UICC III) had a lower expression of Topo II $\alpha$ compared to patients in early tumour stages (UICC I + II) $(p=0.029)$. Interestingly, the histological grading did not show any coherence to the expression of Topo II $\alpha$. In terms of histological entities, the adeno carcinoma displayed higher expression profiles than other entities $(p=0.041)$. All data is presented in Additional file 4: Table S1.

\section{Coherence between topoisomerase II a expression and patient outcome}

In general, low expression rates of Topo II $\alpha$ cohered with a significantly unfavourable outcome $(p=0.010)$ (Fig. $2 \mathrm{a}+\mathrm{b}$ ). The entire cohort was further analysed by differentiating UICC subsets. The subgroups UICC I + II, UICC III and UICC IV were identified. Within the subset of UICC I + II no difference in the OS or PFS could be monitored $(p=0.354$ and $p=0.207)$. In the clinically relevant subset of UICC III patients in OS and PFS, low expression rates of Topo II $\alpha$ was a significant negative prognostic marker $(p=0.004$ and $p=0.020)$. Within the subcategory of UICC IV patients, Topo II $\alpha$ expression was only significantly relevant in the OS ( $p=0.027)$ (Fig. $3 \mathrm{a}+\mathrm{b})$.

Regarding histological grading, Topo II $\alpha$ expression showed a significant effect on the patient OS within G2 tumours $(p<0.001)$ (Table 2).

Analysing the entire cohort and setting the cut-off for Topo II $\alpha$ expression at 50\%, patients above the upper-limit had a highly significant beneficial outcome $(p<0.001)$ with a median OS of $69.2 \%$, in comparison to an OS of $52.9 \%$ in the subset of $<50 \%$ expression of Topo II $\alpha$. Analogue to the above-mentioned findings a high focal expression of Topo II $\alpha$ (high quantity in hotspots) was correlated with a significant beneficial outcome $(p=0.004)$ (Additional file 2: Figure S2 A).

\section{Expression of minichromosome maintenance protein 6 correlated to clinic-pathological characteristics}

A total of 570 tissue specimens were analysed regarding MCMC6. The median expression was $85.8 \%$ while the mean expression was $82.8 \%$ (range 97.0-27.6\%). Based on these findings, the cut-off value of MCM6 expression was set at $85 \%$. In 306 (53.7\%) cases, the expression was $\geq 85 \%$ and in 264 cases (46.3\%) the expression levels were $<85 \%$. An example of MCM6 expression is displayed in Fig. $4 \mathrm{~A}+\mathrm{B}$. Classifying the cohort by UICC stages, advanced tumour stages (III + IV) displayed significantly less expression of MCM compared to locally confined tumours $(p=0.012$ and $p<0.001)$. In terms of histological grading, significantly less MCM6 expression levels were observed in higher differentiated tumours. There was no statistically significant coherence between patient age and the degree of MCM6 expression. All data is presented in Additional file 5: Table S2.

\section{Coherence of minichromosome maintenance protein 6 expression and patient outcome}

The group of patients that were diagnosed with colorectal neoplasm and MCM6 expression levels below 85\%, a
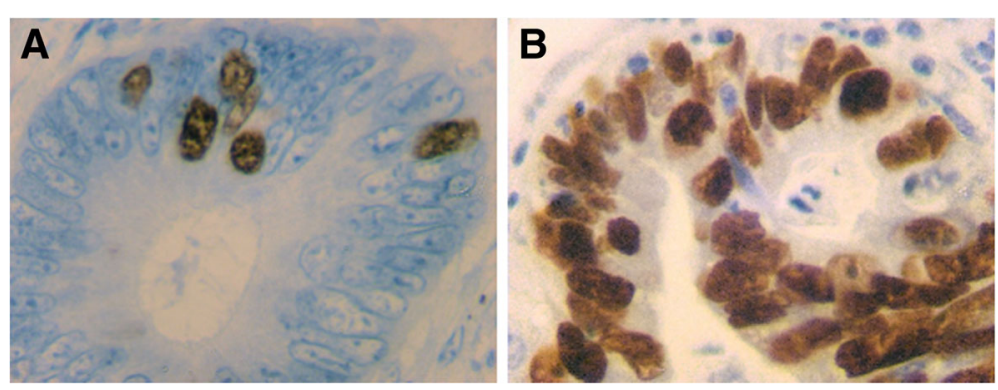

Fig. 1 Topoisomerase lla immunohistochemical staining of colorectal tissue, ABC method $\times 400$ magnification. a with a low $(<50 \%)$ expression level and (b) with high ( $\geq 50 \%$ ) expression levels 
A

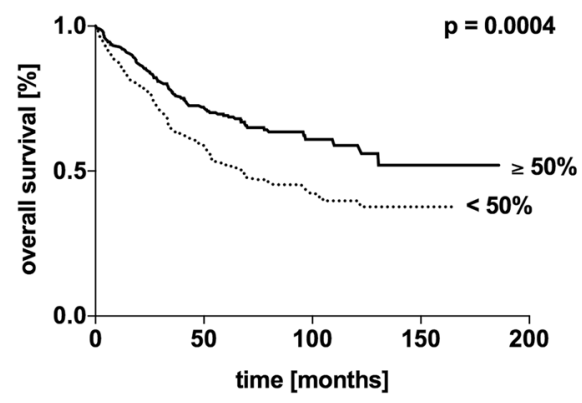

C

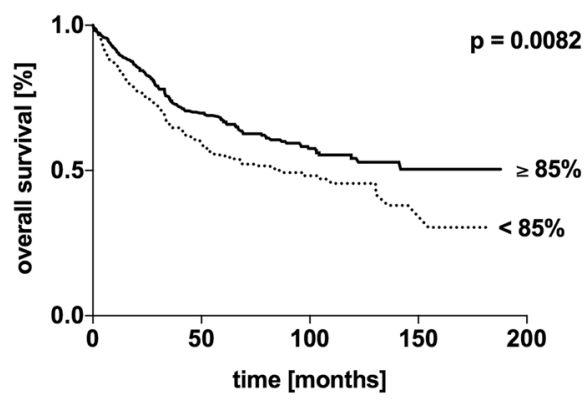

B

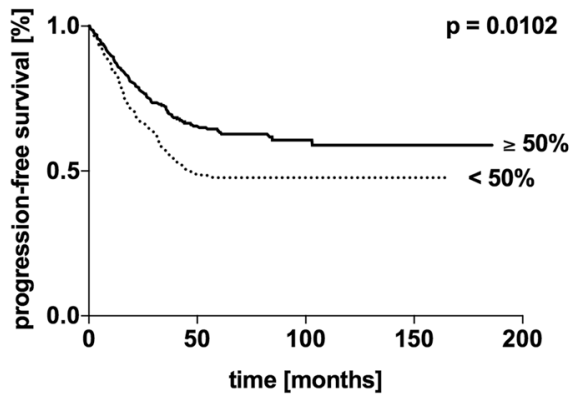

D

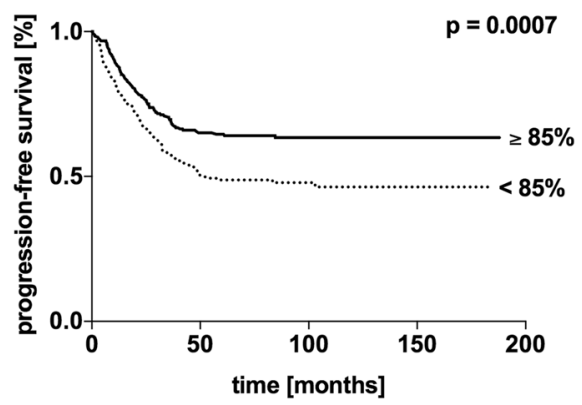

Fig. 2 Kaplan-Meier survival analysis of the cumulative overall survival $(\mathbf{a}, \mathbf{c})$ and progression-free survival $(\mathbf{b}$, $\mathbf{d})$ of patients with colorectal carcinoma stratified by the expression of topoisomerase II $\mathbf{a}(\mathbf{a}, \mathbf{b})$ and minichromosome maintenance protein $6(\mathbf{c}, \mathbf{d})$ according to the cut off. $P$-values were calculated by Log rank tests

A

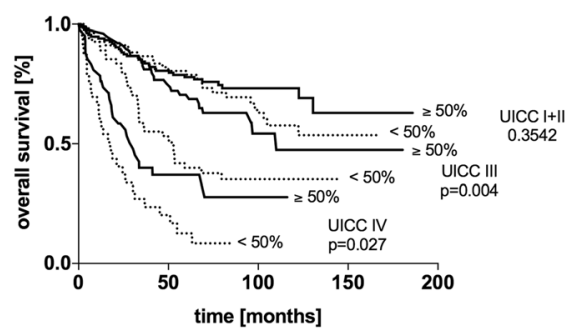

C

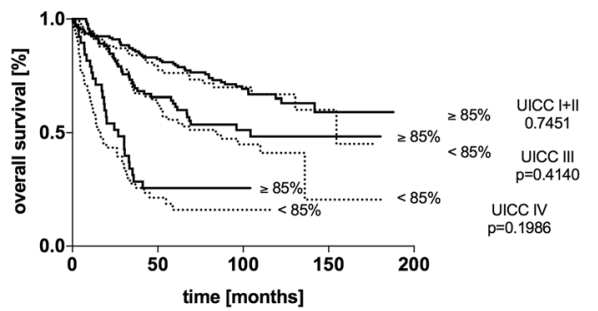

B

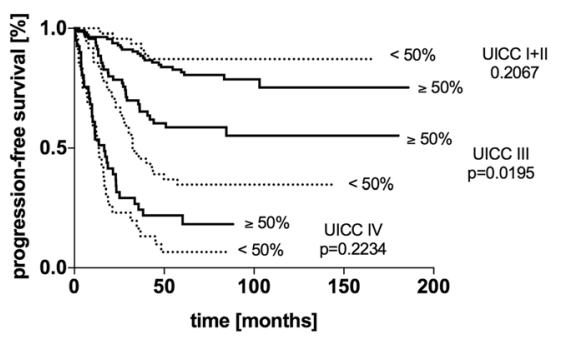

D

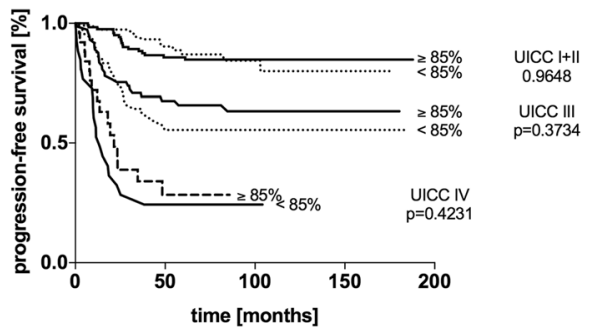

Fig. 3 Kaplan-Meier survival analysis of the cumulative overall survival $(\mathbf{a}, \mathbf{c})$ and progression-free survival (b, d) of patients with colorectal carcinoma stratified by the UICC stages I + II, III and IV. Each subset was analysed in respect to topoisomerase II $\mathbf{a}(\mathbf{a}, \mathbf{b})$ and minichromosome maintenance protein 6 expression $(\mathbf{c}, \mathbf{d})$. P-values were calculated by Log rank tests 
Table 2 IHC expression of topoisomerase II a and correlation to the patients' outcome

\begin{tabular}{|c|c|c|c|c|c|c|c|}
\hline & $\mathrm{N}$ & OS [mo & & & DFS [mc & & \\
\hline & & expressi & & & expressi & & \\
\hline & & $>50 \%$ & $\leq 50 \%$ & $\mathrm{p}$ & $>50 \%$ & $\leq 50 \%$ & $p$ \\
\hline all & 430 & n.a. & 68.4 & $<0.001$ & n.a. & 48.4 & 0.010 \\
\hline age (years) & & & & & & & \\
\hline$<65$ & 211 & n.a. & 95.7 & $<0.001$ & n.a. & n.a. & 0.111 \\
\hline$\geq 65$ & 215 & 110.1 & 53.6 & 0.188 & n.a. & n.a. & 0.959 \\
\hline tumor site & & & & & & & \\
\hline right colon & 115 & 122.6 & 58.9 & 0.313 & n.a. & n.a. & 0.197 \\
\hline left colon + rectum & 298 & n.a. & 68.4 & $<0.001$ & n.a. & n.a. & 0.797 \\
\hline UICC & & & & & & & \\
\hline $\mid+\|$ & 217 & n.a. & n.a. & 0.354 & n.a. & n.a. & 0.207 \\
\hline III & 133 & 110.1 & 51.9 & 0.004 & n.a. & 32.4 & 0.020 \\
\hline IV & 76 & 30.2 & 17.6 & 0.027 & 16.6 & 13.6 & 0.223 \\
\hline histological grading & & & & & & & \\
\hline । & 9 & n.a. & n.a. & n.a. & n.a. & n.a. & 0.480 \\
\hline$\|$ & 339 & n.a. & 66.1 & $<0.001$ & n.a. & n.a. & 0.283 \\
\hline III & 67 & 98.6. & 28.8 & 0.207 & n.a. & n.a. & 0.390 \\
\hline histology & & & & & & & \\
\hline adeno carcinoma & 364 & n.a. & 68.4 & $<0.001$ & n.a. & n.a. & 0.259 \\
\hline mucinous + signet-ring carcinoma & 56 & 59.1 & 53.6 & 0.881 & n.a. & n.a. & 0.923 \\
\hline resection margin & & & & & & & \\
\hline Ro & 404 & n.a. & 58.9 & 0.009 & n.a. & n.a. & 0.299 \\
\hline $\mathrm{R} 1+\mathrm{R} 2$ & 18 & 58.0 & 68.4 & 0.168 & 54.4 & 47.8 & 0.797 \\
\hline
\end{tabular}

All $P$ values in bold, are regarded as statistically significant. Abbreviations: UICC Union internationale contre le cancer, n.a. not achieved

significantly poor OS $(p=0.008)$ and PFS $(p<0.001)$ were monitored in the univariate analysis (Fig. $2 \mathrm{c}+\mathrm{d}$ ). Stratifying the cohort by means of the UICC staging, different to Topo II $\alpha$ expression, MCM6 expression did not correlate with a statistically poor OS or PFS in any of the UICC-subgroups (Fig. $3 \mathrm{c}+\mathrm{d}$ ). However, categorizing by age groups, in young patients ( $<65$ years), MCM6 expression levels were linked significantly to a poorer outcome. Regarding histological grading, within the subset of G2 patients, an expression rate above $85 \%$ was linked to a significantly poorer outcome (Table 3). Similar to the focal Topo II $\alpha$ expression, MCM6 hotspots were correlated to a poor patient outcome $(p=0.013)$ (Additional file 2: Figure S2 B).

\section{Comparison of MCM6 and topo II a expression levels}

In the entire cohort, MCM6 expression was significantly higher (mean 82.8\%) than the expression of Topo II $\alpha$ (mean 52.0\%) $(p<0.001)$ (Additional file 3: Figure S3 A). Furthermore, a significant correlation $(\mathrm{r}=0.433, p<0.001)$

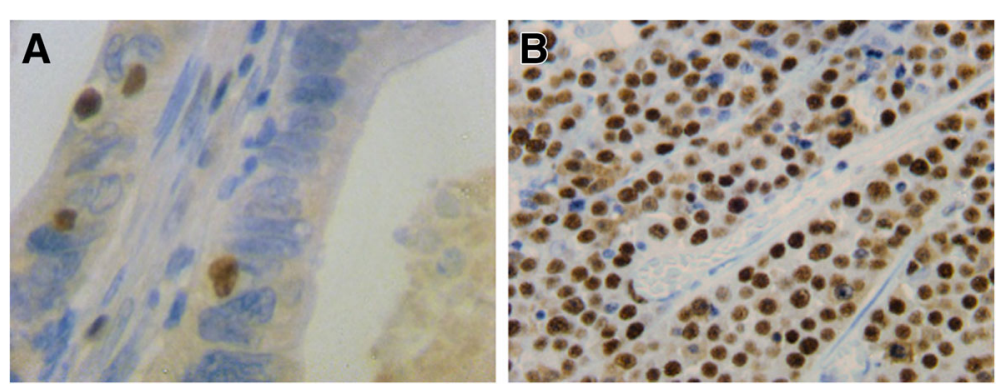

Fig. 4 Minichromosome Maintenance Protein 6 immunohistochemical staining of colorectal tissue, $A B C$ method $\times 400$ magnification. a with a low $(<85 \%)$ expression level and (b) with high $(\geq 85 \%)$ expression levels 
Table $\mathbf{3}$ IHC expression of minichromosome maintenance protein 6 and correlation to the patients' outcome

\begin{tabular}{|c|c|c|c|c|c|c|c|}
\hline & $N$ & OS $[\mathrm{mc}$ & & & DFS $[\mathrm{m}$ & & \\
\hline & & express & & & express & & \\
\hline & & $>85 \%$ & $\leq 85 \%$ & $\mathrm{p}$ & $>85 \%$ & $\leq 85 \%$ & $\mathrm{p}$ \\
\hline all & 570 & n.a. & 87.0 & 0.008 & n.a. & 51.0 & 0.001 \\
\hline age (years) & & & & & & & \\
\hline$<65$ & 270 & n.a. & 136.0 & 0.007 & n.a. & n.a. & 0.418 \\
\hline$\geq 65$ & 280 & 82.0 & 51.9 & 0.246 & n.a. & n.a. & 0.419 \\
\hline tumor site & & & & & & & \\
\hline right colon & 162 & 104.3 & 49.8 & 0.026 & n.a. & n.a. & 0.135 \\
\hline left colon + rectum & 385 & n.a. & 110.1 & 0.086 & n.a. & n.a. & 0.658 \\
\hline UICC & & & & & & & \\
\hline $1+\|$ & 262 & 154.6 & 154.6 & 0.745 & n.a. & n.a. & 0.965 \\
\hline III & 184 & 84.0 & 84.0 & 0.414 & n.a. & n.a. & 0.373 \\
\hline IV & 101 & 16.4 & 16.4 & 0.199 & 13.6 & 21.5 & 0.423 \\
\hline histological grading & & & & & & & \\
\hline 1 & 9 & n.a. & n.a. & n.a. & n.a. & n.a. & n.a. \\
\hline$\|$ & 448 & n.a. & 104.9 & 0.008 & n.a. & n.a. & 0.149 \\
\hline III & 92 & 104.3 & 33.7 & 0.393 & n.a. & n.a. & 0.839 \\
\hline histology & & & & & & & \\
\hline adeno carcinoma & 466 & n.a. & 104.9 & 0.026 & n.a. & n.a. & 0.837 \\
\hline mucinous + signet-ring carcinoma & 75 & 11.3 & 41.9 & 0.103 & n.a. & 34.7 & 0.006 \\
\hline resection margin & & & & & & & \\
\hline Ro & 509 & n.a. & 130.5 & 0.115 & n.a. & n.a. & 0.244 \\
\hline$R 1+R 2$ & 29 & 11,3 & 15.3 & 0.308 & 9,7 & n.a. & 0.001 \\
\hline
\end{tabular}

All $P$ values in bold, are regarded as statistically significant. Abbreviations: UICC - Union internationale contre le cancer; n.a. - not achieved

between the expression of both proliferative markers was observed (Additional file 3: Figure S3 B). Corresponding to this, the analysis of hot spots was significantly higher in MCM6 than Topo II $\alpha(p<0.001)$ (Additional file 3: Figure S3 C).

\section{Conclusions}

Colorectal carcinoma is a major tumour entity and is accountable for the second greatest cause of death in tumour patients [19]. In assessment of the prognosis, prognostic markers are required in addition to the UICC-staging. Dysfunctional cell proliferation plays a key role in neoplasms. Evaluation of proliferative markers in the routine diagnosis of carcinomas is essential. For example, IHC of the proliferative marker Ki-67 is well accepted and executed on a regular basis. High levels of Ki-67 expression indicate rapid tumour growth and are associated with a poor clinical outcome [20-23]. Regarding colorectal carcinoma, contradictory conclusions concerning the proliferation markers have been made. Multiple studies described high expression levels of Ki-67 to be a negative prognostic marker [23-25], whereas other studies came to the opposite conclusion
[26]. A few studies did not monitor any impact of the Ki-67 expression levels on the clinical outcome [27].

In this study we focused on two key player proteins in cell division, the topoisomerase II $\alpha$ (Topo II $\alpha$ ) and minichromosome maintenance protein 6 (MCM6). We here applied IHC of Topo II $\alpha$ and MCM6 to a large and representative cohort of patients diagnosed with colorectal carcinoma.

IHC analysis was performed in order to detect the expression levels of Topo II $\alpha$ using the primary antibody Ki-S4, developed in the Institute of Haematopatholgy at the University Hospital Kiel. The antibody was proven to be a specific marker for Topo II $\alpha$ [8]. The expression of Topo II $\alpha$ was previously shown to be a significant prognostic indicator in breast cancer and mantel cell lymphoma, where a high intensity of expression was linked to a poor clinical outcome $[5,28]$. Data of IHC for the detection of Topo II $\alpha$ expression in large and representative cohorts of CRC patients are limited. Boonsong et al. performed IHC to detect Topoisomerase I levels in 249 CRC patients but was unable to find a correlation neither to histo-pathological characteristics, nor to OS [29]. However, another recent study does 
reveal a significant correlation in terms of prolonged DFS and OS in patients with high expression rates of Topoisomerase I [30]. Our analysis also revealed a highly significant correlation between the Topo II $\alpha$ expression and the OS and DFS. Synoptically, our data is partially contradictory to previous studies. Lacking analysis of Topo II $\alpha$ in reasonably sized cohorts of patients suffering of CRC, validation is critical. Regarding the patient age, a significant coherence to Topo II $\alpha$ expression was monitored. In young patients ( $\leq 65$ years), the expression was significantly higher which is likewise a contrary result to the study of Boonsong et al. [29]. Furthermore, within the cohort of younger patients, we were able to identify Topo II $\alpha$ expression as a prognostic marker. High expression rates cohered with a beneficial clinical outcome. As to why the prognostic value is only in the subset of young patients must be further explored - experimental validation is currently lacking.

CRC localised at the right hemi colon is generally associated with an inferior prognosis, we therefore expected expression levels of Topo II $\alpha$ to be significantly lower. To our surprise, the locus of neoplasia (left vs right hemi colon) did not prove any difference in expression rates of Topo II $\alpha$. Patients diagnosed with an adeno carcinoma and Topo II $\alpha$ expression levels above the cut-off showed a highly significant favourable outcome.

Locally advanced tumour progression is accompanied with lower rates of Topo II $\alpha$ expression. Comparing UICC I + II with UICC III, a significant decrease in expression was monitored. Between UICC III and UICC IV, no difference was asserted. Within each UICC stage, significant impact of Topo II $\alpha$ expression levels on the clinical outcome was observed. These findings prove the prognostic impact of assessing Topo II $\alpha$ expression levels using IHC. In conclusion, our data provides an additional tool to the UICC classification in terms of prognosis and clinical outcome to identify Patients at risk, which may be of benefit to an (neo-) adjuvant treatment.

In further analysis, we assessed the expression levels of MCM6 and clinical characteristics, as well as patient outcome. CRC tissue specimens of a large cohort of patients were studied using IHC with the primary antibody Ki-MCM6, that is highly specific to the MCM6. The relevance of MCM in malignancies has been affirmed in various studies [15-17, 31]. An analysis of MCM6 in patients diagnosed with CRC was absent.

As expected, the mean expression level of MCM6 (83\%) was significantly higher than with Topo II $\alpha$ (52\%). MCM6 is involved in the early phase of cell cycle replication. The protein is partly involved in the $G_{1}$ phase. Hence, a larger quantity of cells (including cells in early stages of the cell cycle) is stained by IHC [13].
The above-mentioned finding may explain the different quantity of expression when comparing Topo II $\alpha$ with MCM6. Similar results have been demonstrated in other tumour entities [6]. Correlation of Topo II $\alpha$ and MCM6 was clearly demonstrated. Neoplastic tissue with low expression levels of MCM6 exhibited low levels of Topo II $\alpha$ expression.

We did not expect that MCM6 expression levels would negatively correlate with the UICC staging. In progressive tumours, lower expression levels of MCM6 were observed, which is contrary to the Topo II $\alpha$ expression levels in our cohort. We expected high levels of MCM6 in advanced tumours with rapid tumour growth and subsequent greater cell proliferation as previously described by Giaginis et al. in terms of MCM2 expression [32].

Concerning the OS and DFS, expression levels above the cut-off were associated with a favourable outcome. Furthermore, in young patients ( $\leq 65$ years) with histologically graded G2 adeno carcinoma, MCM6 expression levels above the cut-off also demonstrated a significant marker for a beneficial outcome.

For the first time our study presents data of Topo II $\alpha$ and MCM6 IHC detected expression levels in a large representative cohort of patients diagnosed with CRC. Contrary to the expected outcome, high expression levels of the proliferative markers MCM6 and Topo II $\alpha$ represent a significantly negative prognostic marker.

Increased cell proliferation was generally thought to be responsible for tumour progression and metastasizing. Whereby, as suggested by our data, rather poorly differentiated tumours with scarce cell proliferation seem to be liable for a poor progression of the disease.

In summary, we propose that from a prognostic point of view, high proliferative cell turnover should not be equated with a poor histological tumour differentiation. We finally conclude that assessing the proliferative turnover could be used for risk stratification of CRC patients in the future. Undoubtedly, our data is controversial in context of other malignancies, but carcinomas are diverse, and should not all be investigated in analogy. In this MS we present genuine data exhibiting novel findings in MCM6 and Topo II alpha exploration, that truthfully cannot be elucidated in any manner. A more in-depth investigation is required in order to demonstrate and consolidate our findings in validation cohorts.

\section{Additional files}

Additional file 1: Figure S1 A + B. Kaplan-Meier analysis of the cumulative overall (A) and progression-free (B) survival of patients with a colorectal carcinoma and staged according to the UICC classification. The $p$ value was calculated by log-rank test. (TIFF 398 kb) 
Additional file 2: Figure S2 A + B. Kaplan-Meier analysis of the cumulative overall survival of patients with a colorectal carcinoma and stratified by the characteristic of hotspots of (A) topoisomerase II alpha and (B) minichromosome maintenance protein 6 expression. The occurrence of hotspots significantly correlates with a worse patients' outcome. The $p$ value was calculated by log-rank test. (TIFF $488 \mathrm{~kb}$ )

Additional file 3: Figure S3 A-C. (A) Expression levels of topoisomerase II alpha and minichromosome maintenance protein 6. (B) Significant correlation ( $r=0.433, p<0.001$ ) between both proliferative markers. (C) Frequency of hot spots within the entire cohort. (TIFF $521 \mathrm{~kb}$ )

Additional file 4: Table S1. Coherence of topoisomerase II alpha IHC expression to clinical and histological criteria. (XLSX $9 \mathrm{~kb}$ )

Additional file 5: Table S2. Coherence of minichromosome maintenance protein $6 \mathrm{IHC}$ expression to clinical and histological criteria. (XLSX $9 \mathrm{~kb})$

\section{Abbreviations}

CRC: Colorectal cancer; FAP: Familial adenomatous polyposis; FISH: Fluorescent in situ hybridization; HNPCC: Hereditary nonpolyposis colorectal cancer; MCM6: Minichromosome maintenance protein 6; MMR: Mismatch repair gene systems; MSI: Microsatellite instability; OS: Overall survival; PCNA: Proliferating cell nuclear antigen; PFS: Progression-free survival; TNM: TNM Classification of Malignant Tumours; Topo Ila: Topoisomerase II alpha; UICC: Union for International Cancer Control

\section{Acknowledgements}

Not applicable.

\section{Funding}

This research did not receive any specific grant from funding agencies in the public, commercial, or not-for-profit sectors.

\section{Availability of data and materials}

The datasets used and/or analysed during the current study are available from the corresponding author on reasonable request.

\section{Authors' contributions}

$\mathrm{AH}$ data analysis, composed manuscript, FG data collection, revised the manuscript, SN data analysis, slide analysis, composed manuscript, JHB slide analysis, revised the manuscript, RL slide preparation, revised the manuscript, BS slide staining and data analysis, JHC data collection, composed manuscript, TB composed manuscript, SH data collection, composed manuscript, GB data collection, revised the manuscript, ClS data collection, composed manuscript, CaS data collection and analysis, composed manuscript. All authors have read and approved the manuscript.

\section{Ethics approval and consent to participate}

The study was approved by the local ethics committee of the Medical Faculty, Christian-Albrechts University Kiel (reference no. A110/99) and performed in accordance with the Declaration of Helsinki. All patients participating in this study, gave their written informed consent.

\section{Consent for publication}

Not applicable.

\section{Competing interests}

The authors declare that they have no competing interests.

\section{Publisher's Note}

Springer Nature remains neutral with regard to jurisdictional claims in published maps and institutional affiliations.

\section{Author details}

${ }^{1}$ Department of General and Thoracic Surgery, University Hospital Schleswig-Holstein, Campus Kiel, Arnold-Heller Str. 3, Hs. 18, 24105 Kiel, Germany. ${ }^{2}$ First Department of Medicine, UKSH, Campus Lübeck, Lübeck, Germany. ${ }^{3}$ Department of Medicine, Baruch Padeh Poria Medical Center, Faculty of Medicine in the Galilee, Bar-Ilan University, Tiberias, Lower Galilee, Israel. ${ }^{4}$ Institute of Pathology, Hannover Medical School, Hannover, Germany.
${ }^{5}$ Institute of Anatomy, University of Kiel, Kiel, Germany. ${ }^{6}$ Institute of Pathology, University of Tübingen, Tübingen, Germany. ${ }^{7}$ Clinic of Forensic Psychiatry Nette-Gut, Weißenthurm, Germany. ${ }^{8}$ Praxis Dr. Schrader, Kiel, Germany.

Received: 1 October 2018 Accepted: 23 April 2019

Published online: 09 May 2019

\section{References}

1. Fearon ER, Vogelstein B. A genetic model for colorectal tumorigenesis. Cell. 1990;61(5):759-67.

2. Brenner H, Kloor M, Pox CP. Colorectal cancer. Lancet. 2014;383(9927): 1490-502.

3. Gerdes J, Lemke H, Baisch H, Wacker HH, Schwab U, Stein H. Cell cycle analysis of a cell proliferation-associated human nuclear antigen defined by the monoclonal antibody Ki-67. J Immunol. 1984;133(4):1710-5.

4. Li LT, Jiang G, Chen Q, Zheng JN. Ki67 is a promising molecular target in the diagnosis of cancer (review). Mol Med Rep. 2015;11(3):1566-72.

5. Schrader C, Meusers P, Brittinger G, Teymoortash A, Siebmann JU, Janssen D, Parwaresch $\mathrm{R}$, Tiemann M. Topoisomerase llalpha expression in mantle cell lymphoma: a marker of cell proliferation and a prognostic factor for clinical outcome. Leukemia. 2004;18(7):1200-6.

6. Schrader C, Janssen D, Klapper W, Siebmann JU, Meusers P, Brittinger G, Kneba M, Tiemann M, Parwaresch R. Minichromosome maintenance protein 6, a proliferation marker superior to Ki-67 and independent predictor of survival in patients with mantle cell lymphoma. Br J Cancer. 2005;93(8):939-45.

7. Champoux JJ. DNA topoisomerases: structure, function, and mechanism. Annu Rev Biochem. 2001;70:369-413.

8. Kellner U, Heidebrecht HJ, Rudolph P, Biersack H, Buck F, Dakowski T, Wacker HH, Domanowski M, Seidel A, Westergaard O, et al. Detection of human topoisomerase II alpha in cell lines and tissues: characterization of five novel monoclonal antibodies. J Histochem Cytochem. 1997;45(2):251-63.

9. Rudolph $\mathrm{P}$, Olsson H, Bonatz G, Ratjen V, Bolte H, Baldetorp B, Ferno M, Parwaresch R, Alm P. Correlation between p53, c-erbB-2, and topoisomerase II alpha expression, DNA ploidy, hormonal receptor status and proliferation in 356 node-negative breast carcinomas: prognostic implications. J Pathol. 1999:187(2):207-16.

10. Rudolph P, MacGrogan G, Bonichon F, Frahm SO, de Mascarel I, Trojani M, Durand M, Avril A, Coindre JM, Parwaresch R. Prognostic significance of Ki67 and topoisomerase llalpha expression in infiltrating ductal carcinoma of the breast. A multivariate analysis of 863 cases. Breast Cancer Res Treat. 1999:55(1):61-71.

11. Provencio M, Corbacho C, Salas C, Millan I, Espana P, Bonilla F, Ramon Cajal $\mathrm{S}$. The topoisomerase Ilalpha expression correlates with survival in patients with advanced Hodgkin's lymphoma. Clin Cancer Res. 2003;9(4):1406-11.

12. Riera A, Barbon M, Noguchi $Y$, Reuter LM, Schneider S, Speck C. From structure to mechanism-understanding initiation of DNA replication. Genes Dev. 2017:31(11):1073-88.

13. Heidebrecht HJ, Buck F, Endl E, Kruse ML, Adam-Klages S, Andersen K, Frahm SO, Schulte C, Wacker HH, Parwaresch R. Ki-Mcm6, a new monoclonal antibody specific to Mcm6: comparison of the distribution profile of Mcm6 and the Ki-67 antigen. Lab Investig. 2001;81(8):1163-5.

14. Helfenstein A, Frahm SO, Krams M, Drescher W, Parwaresch R, Hassenpflug J. Minichromosome maintenance protein (MCM6) in low-grade chondrosarcoma: distinction from enchondroma and identification of progressive tumors. Am J Clin Pathol. 2004;122(6):912-8.

15. Kwok HF, Zhang SD, McCrudden CM, Yuen HF, Ting KP, Wen Q, Khoo US, Chan KY. Prognostic significance of minichromosome maintenance proteins in breast cancer. Am J Cancer Res. 2015:5(1):52-71.

16. Deraco M, Cabras A, Baratti D, Kusamura S. Immunohistochemical evaluation of Minichromosome maintenance protein 7 (MCM7), topoisomerase llalpha, and Ki-67 in diffuse malignant peritoneal mesothelioma patients using tissue microarray. Ann Surg Oncol. 2015:22(13):4344-51.

17. Wu W, Wang X, Shan C, Li Y, Li F. Minichromosome maintenance protein 2 correlates with the malignant status and regulates proliferation and cell cycle in lung squamous cell carcinoma. Onco Targets Ther. 2018;11:5025-34.

18. Bankfalvi A, Riehemann K, Ofner D, Checci R, Morgan JM, Piffko J, Bocker W, Jasani B, Schmid KW. Moist autoclaving. A simplified method for antigen unmasking Pathologe. 1994;15(6):345-9.

19. Siegel RL, Miller KD, Fedewa SA, Ahnen DJ, Meester RGS, Barzi A, Jemal A. Colorectal cancer statistics, 2017. CA Cancer J Clin. 2017;67(3):177-93. 
20. Chen X, He C, Han D, Zhou M, Wang Q, Tian J, Li L, Xu F, Zhou E, Yang K. The predictive value of Ki-67 before neoadjuvant chemotherapy for breast cancer: a systematic review and meta-analysis. Future Oncol. 2017;13(9):843-57.

21. Luo G, Hu Y, Zhang Z, Wang P, Luo Z, Lin J, Cheng C, Yang Y.

Clinicopathologic significance and prognostic value of Ki-67 expression in patients with gastric cancer: a meta-analysis. Oncotarget. 2017;8(30):50273-83.

22. Berlin A, Castro-Mesta JF, Rodriguez-Romo L, Hernandez-Barajas D, Gonzalez-Guerrero JF, Rodriguez-Fernandez IA, Gonzalez-Conchas G, Verdines-Perez A, Vera-Badillo FE. Prognostic role of Ki-67 score in localized prostate cancer: a systematic review and meta-analysis. Urol Oncol. 2017:35(8):499-506.

23. Wang L, Liu Z, Fisher KW, Ren F, Lv J, Davidson DD, Baldridge LA, Du X, Cheng L. Prognostic value of programmed death ligand 1, p53, and Ki-67 in patients with advanced-stage colorectal cancer. Hum Pathol. 2018;71:20-9.

24. Melling N, Kowitz CM, Simon R, Bokemeyer C, Terracciano L, Sauter G, Izbicki JR, Marx AH. High Ki67 expression is an independent good prognostic marker in colorectal cancer. J Clin Pathol. 2016;69(3):209-14.

25. Cidado J, Wong HY, Rosen DM, Cimino-Mathews A, Garay JP, Fessler AG, Rasheed ZA, Hicks J, Cochran RL, Croessmann S, et al. Ki-67 is required for maintenance of cancer stem cells but not cell proliferation. Oncotarget. 2016;7(5):6281-93.

26. Allegra CJ, Paik S, Colangelo LH, Parr AL, Kirsch I, Kim G, Klein P, Johnston PG, Wolmark N, Wieand HS. Prognostic value of thymidylate synthase, Ki-67, and p53 in patients with Dukes' B and C colon cancer: a National Cancer Institute-National Surgical Adjuvant Breast and bowel project collaborative study. J Clin Oncol. 2003;21(2):241-50.

27. Shin IY, Sung NY, Lee YS, Kwon TS, Si Y, Lee YS, Oh ST, Lee IK. The expression of multiple proteins as prognostic factors in colorectal cancer: cathepsin $\mathrm{D}$, p53, COX-2, epidermal growth factor receptor, C-erbB-2, and Ki-67. Gut Liver. 2014:8(1):13-23.

28. An X, Xu F, Luo R, Zheng Q, Lu J, Yang Y, Qin T, Yuan Z, Shi Y, Jiang W, et al. The prognostic significance of topoisomerase II alpha protein in early stage luminal breast cancer. BMC Cancer. 2018;18(1):331.

29. Boonsong A, Curran S, McKay JA, Cassidy J, Murray Gl, McLeod HL. Topoisomerase I protein expression in primary colorectal cancer and lymph node metastases. Hum Pathol. 2002;33(11):1114-9.

30. Shaojun $\mathrm{C}$, Li H, Haixin H, Guisheng L. Expression of topoisomerase 1 and carboxylesterase 2 correlates with irinotecan treatment response in metastatic colorectal cancer. Cancer Biol Ther. 2018;19(3):153-9.

31. Ishibashi Y, Kinugasa T, Akagi Y, Ohchi T, Gotanda Y, Tanaka N, Fujino S, Yuge K, Kibe S, Yoshida N, et al. Minichromosome maintenance protein 7 is a risk factor for recurrence in patients with dukes $\mathrm{C}$ colorectal cancer. Anticancer Res. 2014;34(8):4569-75.

32. Giaginis C, Georgiadou M, Dimakopoulou K, Tsourouflis G, Gatzidou E, Kouraklis G, Theocharis $S$. Clinical significance of MCM-2 and MCM-5 expression in colon cancer: association with clinicopathological parameters and tumor proliferative capacity. Dig Dis Sci. 2009;54(2):282-91.

Ready to submit your research? Choose BMC and benefit from:

- fast, convenient online submission

- thorough peer review by experienced researchers in your field

- rapid publication on acceptance

- support for research data, including large and complex data types

- gold Open Access which fosters wider collaboration and increased citations

- maximum visibility for your research: over $100 \mathrm{M}$ website views per year

At BMC, research is always in progress.

Learn more biomedcentral.com/submissions 